\title{
Enhanced utilisation of voltage control resources with distributed generation
}

DOI:

10.1109/PES.2011.6039085

Link to publication record in Manchester Research Explorer

\section{Citation for published version (APA):}

Ochoa, L. F., Keane, A., Vittal, E., Dent, C. J., \& Harrison, G. P. (2011). Enhanced utilisation of voltage control resources with distributed generation. In IEEE/PES General Meeting 2011 (pp. 1-1)

https://doi.org/10.1109/PES.2011.6039085

\section{Published in:}

IEEE/PES General Meeting 2011

\section{Citing this paper}

Please note that where the full-text provided on Manchester Research Explorer is the Author Accepted Manuscript or Proof version this may differ from the final Published version. If citing, it is advised that you check and use the publisher's definitive version.

\section{General rights}

Copyright and moral rights for the publications made accessible in the Research Explorer are retained by the authors and/or other copyright owners and it is a condition of accessing publications that users recognise and abide by the legal requirements associated with these rights.

\section{Takedown policy}

If you believe that this document breaches copyright please refer to the University of Manchester's Takedown Procedures [http://man.ac.uk/04Y6Bo] or contact uml.scholarlycommunications@manchester.ac.uk providing relevant details, so we can investigate your claim.

\section{OPEN ACCESS}




\title{
Enhanced Utilization of Voltage Control Resources With Distributed Generation
}

Andrew Keane, Member, IEEE, Luis (Nando) F. Ochoa, Member, IEEE, Eknath Vittal, Student Member, IEEE,

Chris J. Dent, Member, IEEE, and Gareth P. Harrison, Member, IEEE

\begin{abstract}
Distributed generation (DG) is increasing in penetration on power systems across the world. In rural areas, voltage rise limits the permissible penetration levels of DG. Another increasingly important issue is the impact on transmission system voltages of DG reactive power demand. Here, a passive solution is proposed to reduce the impact on the transmission system voltages and overcome the distribution voltage rise barrier such that more DG can connect. The fixed power factors of the generators and the tap setting of the transmission transformer are determined by a linear programming formulation. The method is tested on a sample section of radial distribution network and on a model of the all island Irish transmission system illustrating that enhanced passive utilization of voltage control resources can deliver many of the benefits of active management without any of the expense or perceived risk, while also satisfying the conflicting objectives of the transmission system operator.
\end{abstract}

